\title{
High Dose Frusemide in Established Acute Renal Failure
}

\author{
F. CANTAROVICH, \\ C. GALLI, \\ L. BENEDETTI, \\ C. CHENA, \\ L. CASTRO, \\ C. CORREA, \\ J. PEREZ LOREDO, J. C. FERNANDEZ, A. LOCATELLI, J. TIZADO
}

\section{Summary}

The results of treatment with frusemide in 105 patients with established acute renal failure admitted during the past six years were reviewed and compared with control groups. Daily doses of $2,000 \mathrm{mg}$ of frusemide administered from the day of admission onwards produced a significant increase in the number of patients who attained a diuresis and decreased the duration of oliguria.

The reduction in the time spent in hospital and in the number of dialyses required suggests that the use of frusemide in these large doses is indicated in patients with severe established acute renal failure.

\section{Introduction}

The use of frusemide in acute renal failure began in 1965 and is now widely accepted (Postgraduate Medical fournal, 1971). Nevertheless, the results obtained by different authors are dissimilar (Beroniade, 1968; Castro et al., 1969; Desmonts et al., 1970; Cantarovich et al., 1971; Fries, et al., 1971; Beaufils, et al., 1972; Humbert et al., 1972; Ollner et al., 1972). There is general agreement that frusemide may have a prophylactic effect, but its therapeutic usefulness in established acute renal failure is not yet established (Stott et al., 1972). The purpose of this paper is to review six years of personal experience with frusemide in established acute renal failure, and to make a critical analysis of our results.

\section{Materials and Methods}

The results obtained in 105 patients with acute oliguric renal failure treated between 1966 and 1972 were reviewed. These patients were selected retrospectively from a larger group on the criterion that they had all required at least two dialyses to ensure that only patients with established renal failure were included. The duration of anuria before admission to the unit was the same for both periods (1966-9, 1969-72) and showed no significant differences between control and frusemide groups (table I). Hence these groups may be regarded as homogeneous-all patients had a proved established acute renal failure with a negative mannitol test $(300 \mathrm{ml} 20 \%$ mannitol given intravenously), urinary sodium $>20 \mathrm{mEq} / \mathrm{l}$. and urinary osmolality equal to or less than serum osmolality; and in every case admission to our unit was necessary in order to perform dialysis treatment. The aetiology of the renal failure is shown in table II.

Renal Unit, Military Central Hospital, Buenos Aires, Argentina F. CANTAROVICH, M.CH., BS.AS., Auxiliary Professor of Medicine, Head of the Renal Unit

C. GALLI, M.D.

L. BENEDETTI, M.D.

C. CHENA, M.D.

L. CASTRO, M.D.

C. CORREA, M.D.

J. PEREZ LOREDO, M.D.

J. C. FERNANDEZ, M.D

A. LOCATELLI, Auxiliary Professor of Medicine

J. TIZADO, M.D.
The severity of the condition was assessed according to the presence of one or more of the following factors: shock, sepsis, haemorrhage, or jaundice. Thus, in a patient with all four features, the severity was regarded as grade 4 ; with three, grade 3 ; and so on.

TABLe I-Duration of Anuria before Admission (in Days)

\begin{tabular}{c|c|c|c|c}
\multicolumn{2}{c|}{} & \multicolumn{2}{c}{$1969-72$} \\
\hline \multirow{2}{*}{ Control } & \multicolumn{2}{c|}{ Frusemide } & \multirow{2}{*}{ Control } & Frusemide \\
\cline { 2 - 5 } & Progressive & Fixed & & \\
\hline $2.8 \pm 0.8$ & $3.1 \pm 0.5$ & $2.7 \pm 0.4$ & $2 \cdot 1 \pm 0.8$ & $2.3 \pm 1 \cdot 1$ \\
\hline
\end{tabular}

TABLE II-Aetiology in the 105 Patients Studied

\begin{tabular}{|c|c|c|c|c|c|c|}
\hline & & & & & $1966-69$ & $1969-72$ \\
\hline 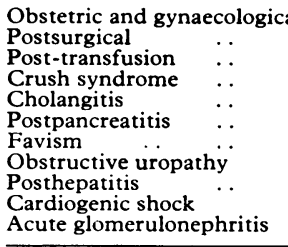 & $\begin{array}{l}\cdots \\
\cdots \\
\cdots \\
\cdots \\
\cdots \\
\cdots \\
\cdots \\
\cdots\end{array}$ & $\begin{array}{l}\cdots \\
\cdots \\
\cdots \\
\cdots \\
\cdots \\
\cdots \\
\cdots \\
\cdots\end{array}$ & $\begin{array}{l}\cdots \\
\therefore \\
\therefore \\
\therefore \\
\therefore \\
\therefore \\
\therefore \\
\cdots\end{array}$ & $\begin{array}{l}\ldots \\
\cdots \\
\cdots \\
\cdots \\
\cdots \\
\cdots \\
\cdots\end{array}$ & $\begin{array}{r}22 \\
14 \\
2 \\
3 \\
4 \\
0 \\
0 \\
0 \\
0 \\
0 \\
2\end{array}$ & $\begin{array}{r}12 \\
27 \\
6 \\
1 \\
6 \\
1 \\
1 \\
1 \\
1 \\
1 \\
1\end{array}$ \\
\hline Total & & & & & 47 & 58 \\
\hline
\end{tabular}

Our methodology varied in two different periods. (a) First period (1966-9). Frusemide was administered to 34 patients; 19 received $600 \mathrm{mg} /$ day (fixed dose group) whereas the remaining 15 were treated with daily doses increasing geometrically from $100 \mathrm{mg} /$ day to $3,200 \mathrm{mg} /$ day (progressive dose group) (Cantarovich et al., 1971). They were simultaneously compared with 13 control patients, randomly selected. (b) Second period (1969-72). Thirty-nine patients were treated with $2,000 \mathrm{mg} /$ day of frusemide and compared with 19 controls. Treatment was allocated on an alternate patient basis and patients selected by the need for two dialyses as mentioned above. Most of our patients were submitted from different hospitals, and in many cases they had been treated previously with frusemide, usually in low and irregular doses. These cases could not be included in the control group; thus the number of control patients in both periods is lower than that of patients treated with frusemide.

Basic treatment for control and frusemide patients consisted of daily dialysis to maintain serum urea and creatinine below $150 \mathrm{mg} / 100 \mathrm{ml}$ and $7 \mathrm{mg} / 100 \mathrm{ml}$ respectively. Alı patients were encouraged to take a satisfactory diet (rich in calories and proteins) whenever possible. Septic states were treated with massive doses of antibiotics.

Frusemide administration was always similar, given intravenously as a single daily dose and with a maximum of $250 \mathrm{mg} /$ hr (diluted in 5\% dextrose). The therapeutic schedule was maintained regardless of urine output, with special attention to water and electrolyte balance. Frusemide was discontinued when serum urea and creatinine levels remained below the above figures without the need for dialysis.

The following factors were analysed: (a) Patients who overcame anuria by achieving $>400 \mathrm{ml} /$ day diuresis. (b) Duration of 
total anuric period. (c) Time to reach 2,000 ml/day diuresis. (d) Time to reach $1.5 \mathrm{mg} / 100 \mathrm{ml}$ serum creatinine. (e) Number of dialyses in recovered patients. $(f)$ Mortality.

\section{Results}

\section{AETIOLOGY}

Postsurgical and obstetric-gynaecological were the most frequent aetiologies in both periods. It is remarkable that the frequency of these two causes changed for each of these periods (table II). There were 22 obstetric-gynaecological and 14 postsurgical cases during the first period against 12 and 27 cases respectively in the second period.

\section{SEVERITY}

Fourteen out of 34 patients in the first period and 31 out of 39 in the second period were in grade 3 or 4 (table III). This difference is statistically significant $(P<0.05)$. No significant differences were noted between the two periods for patients with the other degrees of severity.

TABLE III-Index of Severity

\begin{tabular}{c|c|c}
\hline & \multicolumn{2}{|c}{ No. of Patients } \\
\cline { 2 - 3 } $\begin{array}{c}\text { Severity Score } \\
\text { (see text) }\end{array}$ & $1966-9$ & $1969-72$ \\
\hline 4 & 6 & 15 \\
3 & 8 & 16 \\
2 & 19 & 15 \\
1 & 9 & 9 \\
0 & 5 & 3
\end{tabular}

\section{RESULTS OF TREATMENT (TABLE IV)}

Number of Patients who Achieved $>400 \mathrm{ml} /$ day Diuresis.In the first period there was a significant difference $(P<0.05)$ in this respect between control patients and the group treated with frusemide with the progressive doses. In the second period there was a significant difference $(P<0.05)$ between control and frusemide patients (daily dose 2,000 mg).

Total Anuric Period (in Recovered Patients).-This period was signficantly reduced $(P<0.025)$ in patients treated with the progressive schedule and with $2,000 \mathrm{mg} /$ day $(\mathrm{P}<0.005)$. The difference was not significant in patients treated with $600 \mathrm{mg} /$ day.

Time to Reach 2,000 ml/day Diuresis.-Reductions occurred similar to those in the total anuric period.

Time to Reach Normal $(1.5 \mathrm{mg} / 100 \mathrm{ml})$ Serum Creatinine. -No significant difference was observed between control and frusemide-treated patients.

Number of Dialyses in Recovered Patients.-Patients treated with frusemide required less dialytic treatment than control patients. This difference was significant when frusemide was used in higher doses $(2,000 \mathrm{mg} /$ day $(P<0.05)$ or with. the progressive schedule $(\mathrm{P}<0.025)$.

Mortality.-There were no significant differences between control and patients treated with frusemide.

\section{SIDE EFFECTS}

No side effects were observed with the rate of administration described ( $<250 \mathrm{ml} /$ hour).

\section{Discussion}

The use of frusemide in high doses is a widely accepted procedure in the prophylaxis of incipient acute renal failure, but its efficacy in so-called "established acute renal failure" is still under discussion. For this reason only those patients who required at least two dialyses were included in the present review. Our results showed significant differences in the aetiology of the condition and the degree of severity between the first (1966-9) and the second period (1969-72). We may assume that the significant difference observed in the number of frusemide patients who ovencame anuria when we used high doses $(2,000$ $\mathrm{mg} /$ day or progressive group) compared with the control group is directly related to the use of such high daily doses maintained regardless of the diuretic response. The different results obtained with $600 \mathrm{mg} /$ day together with those reported by other authors suggest that higher daily doses should be given to shonten the anuric period.

The available information (Stott et al., 1972), as well as our personal experience, indicate that there has been an increase in the severity of renal failure in patients admitted to dialysis centres recently. This could be explained by the prophylactic action of frusemide (in patients with reversible oliguria capable of developing an acute renal failure), but also through a therapeutic effect of the drug exerted in cases of less severe acute renal failure (normocatabolic and with fewer complications) which do not require dialytic procedures owing to a shortening of the anuric period.

Though frusemide in high doses has not significantly modified the mortality rate of severe acute renal failure, in our experience the significant differences observed in the course of the disease in those patients who recovered (reduced total anuric period, time to reach $2,000 \mathrm{ml} /$ day diuresis) together with the reduation in the number of dialyses and in the time spent in hospital suggest the use of $2,000 \mathrm{mg} /$ day of frusemide in these patients as a routine.

\section{References}

Beaufils, F., De Myttenaere, I., Rohan, J., and Chapman, A. (1972). Nouvelle

Presse Médicale, 1, 1073 .
Beroniade, V. (1968). Proceedings of the European Dialysis and Transplant Association, 5, 241.

Cantarovich, F., Locatelli, A., Fernandez, J. C., Perez Loredo, J., and Christhot, J. (1971). Postgraduate Medical fournal, 47, April suppl., p. 13.

Castro, L., Gahl, G., and Kessel, M. (1969). Verhandlungen der Deutschen Gesellschaft für Innere Medizin, 75, 130.

Desmonts, J. M., Dentan, M., Andreassian, B., and Weiss, Y. (1970).

Presse Médicale, 78, 1942. 1097.

Humbert, F., Fillastre, J. P., and Lerous, R. (1972). Nouvelle Presse Médicale,

Ollner, M., Grandmillemin, M., and Salvadori, J. M. (1972). Nouvelle Presse Médicale, 1, 270.

Postgraduate Medical fournal, 1971, 47, April suppl.

Stott, R. B., Ogg, C. S., Cameron, J. S., and Bewick, M. (1972). Lancet, 2, 75.

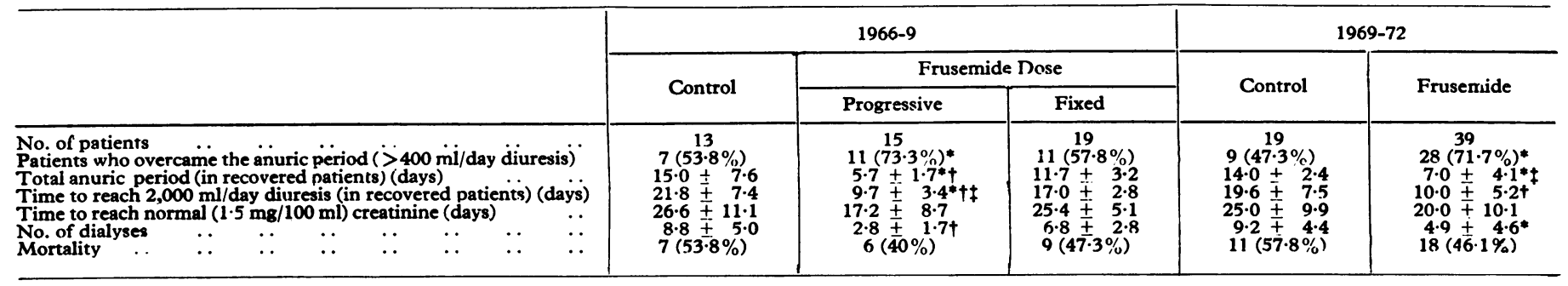

